\title{
Some Remarks on the Nucleolus Organizer of Drosophila hydei and Rhynchosciara americana (Diptera)
}

\author{
T. P. Pessacq-Asenjo \\ Calle 48 \# 1675 (Dto. “A”) (1900) La Plata Argentina
}

Received July 19, 1982

The giant nuclei of cells of salivary glands, Malpighi tubes and other organs of Diptera offers a good model for the analysis of the nucleolar synthesis and structure. The nucleolus and its production by different chromosomal regions have been studied in Drosophila and Hybosciara (Brito da Cunha et al. 1969, Hennig et al. 1975, Schäfer and Kunz 1975). But the problem presents several aspects to solve mainly in what it concerns the exact localization of the chromosomal zone where the nucleolus is organized in different species (Lefevre 1976, Ananiev et al. 1981). The present note deals with the structural rapports existing between the chromocenter and the nucleolus in Drosophila hydei. A comparative analysis is made with the nucleoli of the Malpighi tubes cells of Rhynchosciara americana.

\section{Material and methods}

Larvae of all prepupal stages of Drosophila hydei and fourth instar larvae of Rhynchosciara americana were studied. Salivary glands and Malpighi tubes were dissected, squashed and stained with acetic orcein and lactic acid acetic acid orcein. For autoradiographical studies larvae of Rhynchosciara were injected with $2 \mu$ liters of tritiated uridine $(1,3 \mathrm{c} / \mathrm{mM} ; 0.25 \mathrm{mc} / \mathrm{ml}$, Schwarz) and killed after 30 to 120 minutes. The salivary glands were dissected and squashed. The slides were covered with Kodak AR-10 autoradiographic stripping film. The autoradiograms were stained either with lactic acid acetic acid orcein prior to autoradiography or with Giemsa stain after the autoradiography.

\section{Results}

\section{1) Observations in Drosophila hydei}

In salivary glands as well as in Malpighi tube cells the nucleolar mass is closely related to the chromocenter. The same fact has been reported in Drosophila robusta (Levitan 1970). In those slides where the chromosomes are extended and joined in the fused chromocenter, it is easy to put in evidence the existence of the intranucleolar chromatin. It shows similar characteristics to that described by other authors (Olvera 1969). In most cases it is a thin filament entering the nucleolar mass. This can be seen in Fig. 1. When the chromosomes are disrupted and the nucleolus is broken this thin expansion of the chromocentric nucleolus organizer remains still recognizable. In Drosophila hydei we have not observed nucleolar 
puffs located in the chromosomal arms, similar to that described in other species (Brito da Cunha et al. 1969). We can therefore conclude that in Drosophila hydei the DNA producing the nucleolar RNA pertains in normal conditions to the fused chromocenter.

2) Observations in Rhynchosciara americana

During larval development the cells of salivary glands and Malpighi tubes do not possess a unique nucleolus in this species. In prepupal satges several little nucleoli can be revealed scattered in the nuclear sap (Fig. 4). Sometimes they appear in the center of the nucleus. The centromeric region of the four chromosomes in polytenic nuclei is generally oriented toward the center. By this reason

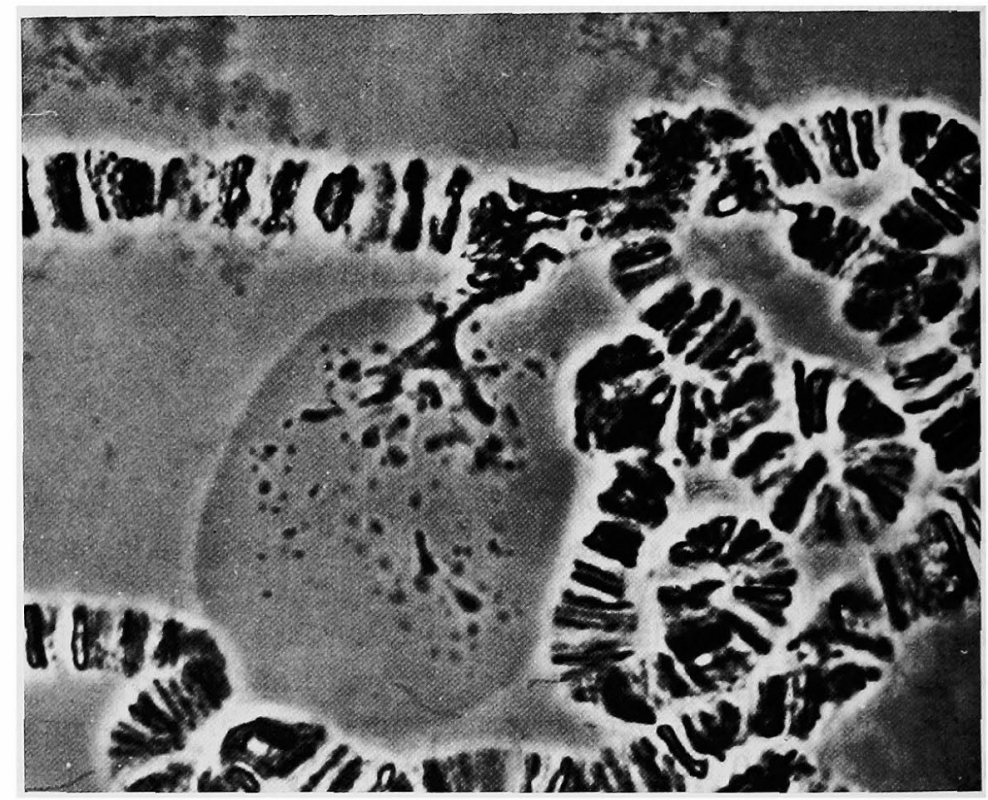

Fig. 1. The nucleolar organizer in Drosophila hydei. To note the chromatinic filament originating from the chromocenter that ramifies inside the nucleolus. Acetic orcein and phase contrast. About $\times 3000$.

the nucleoli appear frequently encircled by the centromeric heterochromatin of the four chromosomes. In other cases the centromeric heterochromatin blocks are applied to the nuclear membrane. As the appearing of the specific puffs takes place, the condensed state of the centromeric chromatin modifies. In some cases we have observed centromeric heterochromatin puffs in contact with the nuclear membrane (Pessacq 1974). Simultaneously, little nucleoli are synthesized at different chromosomic levels. This can be observed in nuclei labelled with tritiated uridine (Fig. 6). A similar phenomenon of micronucleolar formation has been described in this and other species (Brito da Cunha et al. 1969, Pardue et al. 1970, Gerbi 1971, Gambarini 1972) as well as in vegetal cells (Stockert et al. 1969). 

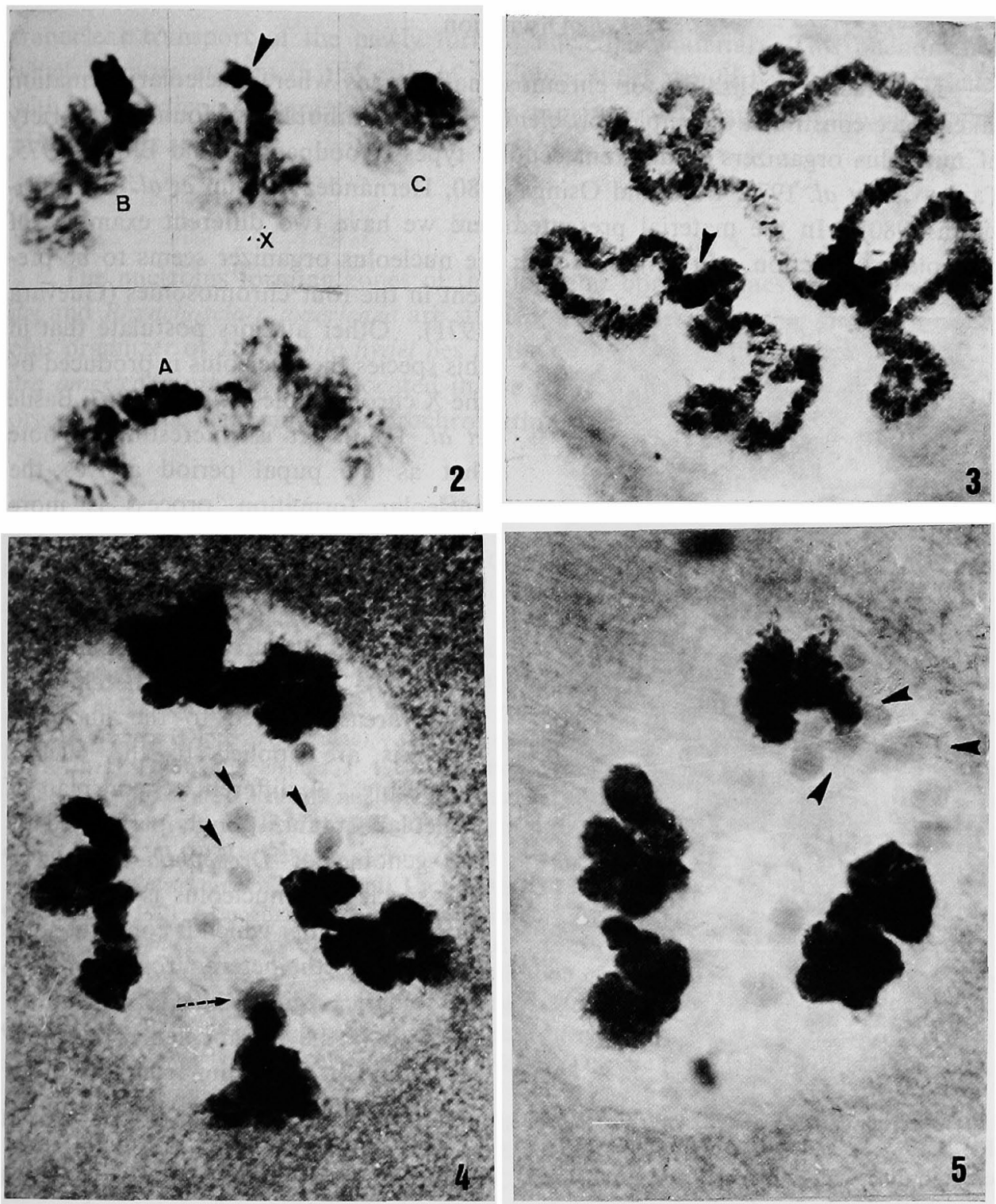

Figs. 2-5. 2, the four chromosomes of Rhynchosciara americana (A, B, C and X) in a cell of the Malpighi tubes during prepupal larval stage. To note the entirely puffed aspect of the $C$ and the double heterochromatic constitution of the centromere of the $\mathrm{X}$ (arrow). Acetic orcein. About $\times 3000$. 3, polytenic chromosomes in Malpighi tubes of Rhynchosciara. B, C and X remain joined at the chromocenter. $\mathrm{A}$ is separated. The arrow signal is centromere. Acetic orcein. About $\times 3000$. 4, non disrupted nucleus of a cell of Malpighi tubes of Rhynchosciara showing the four chromosomes joined to the nuclear membrane and several nucleoli (arrows) in the nuclear cavity. The dotted arrow points out a nucleolar body adherent to the centromeric heterochromatin of the $\mathrm{X}$ chromosome. Acetic orcein. About $\times 3000$. 5, non disrupted nucleus of a cell of Malpighi tubes of Rhynchosciara. The arrows point out several nucleoli related to the centromeric heterochromatin of the X chromosome. Acetic orcein. About $\times 3000$. 


\section{Discussion}

The precise localization of chromosomal regions where nucleolar formation takes place constitutes a complex problem. Several authors have founded a variety of nucleolus organizers in different cellular types (Goodpasture and Bloom 1975, Tantravali et al. 1976, Buys and Osinga 1980, Hernández-Verdun et al. 1980, Privitera 1980). In the material presented here we have two different examples of nucleolar production. In Rhynchosciara the nucleolus organizer seems to be pre-

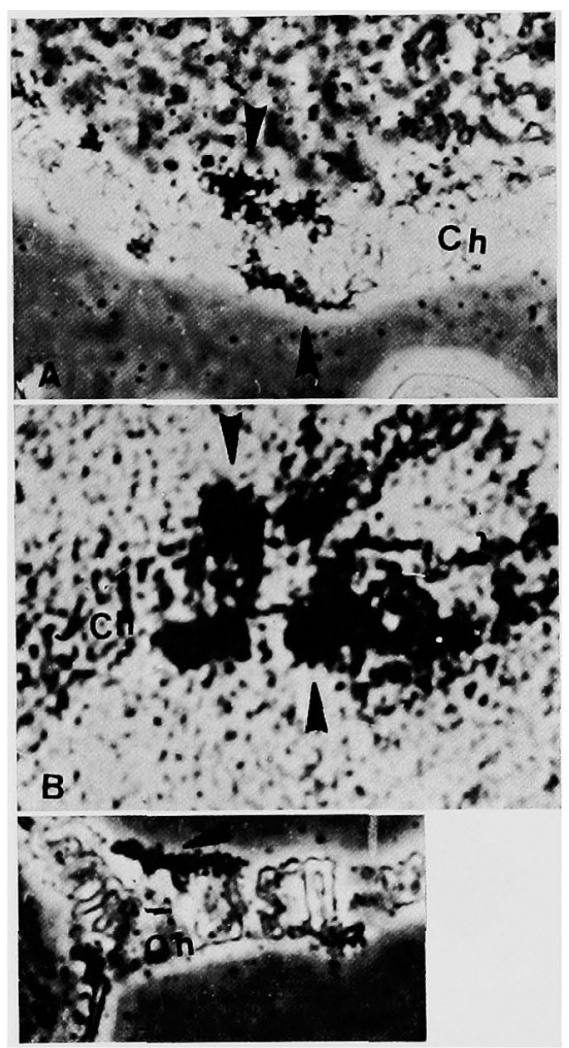

Fig. 6, A, B, and C. Autoradiograms of chromosomes of Rhynchosiara showing micronucleolar bodies (arrows) adherent to the chromosomes (Ch). In $\mathrm{C}$ the labeling is in a single side of the chromosome. Tritiated uridine. Phase contrast. About $\times \mathbf{3 0 0 0}$. sent in the four chromosomes (Guevara 1971). Other authors postulate that in this species the nucleolus is produced by the X chromosomes (Simões 1967, Basile et al. 1970). It is interesting to note that as the pupal period arrives the nucleolar formation process is more intense. In prepupal stages we can observe frequently minute nucleolar bodies adherent to the chromosomes, specially to the centromeric region of the $X$ (Fig. 5), In most cases the chromosomic areas devoted to the nucleolar synthesis are applied to the nuclear membrane. A different general plan of nucleolar organization is performed by the genome of Drosophila hydei. In this species the nucleolus is formed by the chromocenter which is constituted by the fusion of the heterochromatin of the centromeric regions. It is difficult to establish if the intranucleolar chromatinic filament emerging from the chromocenter differentiates at the beginning of the nucleolar RNA synthesis. We can postulate that the chromatinic bud which is always present in the chromocenter, even in the absence of the nucleolar mass, constitutes the nucleolus organizer in these species. This structural characteristics of the nucleolus forming DNA is possibly homologous to that observed in other cellular types (Pessacq and Vidal-Rioja 1975). The differences existing in the nucleolar apparatus of the two studied species would represent the structural counterpart of the differences in the ratio of synthesis and transport to the cytoplasm of the produced RNA. In Rhynchosiara the close contact among the nuclear membrane and nucleolus forming zones of chromosomes and the existence of multiple minute nucleoli would suggest a rapid turn over and ex- 
tranuclear transport of the newly formed nucleolar material. This phenomenon which is more evident in the cells of Malpighi tubes would be in correspondence with the particular characteristics of the pupation and capsule forming mechanisms of this species.

\section{Summary}

The nucleolus forming zones of the polytenic chromosomes of Drosophila hydei and Rhynchosciara americana are studied. It is postulated that the main nucleolus organizer of Drosophila hydei lies in the chromocenter. Those of Rhynchosciara americana are probably located in the four chromosomes, although the main organizer is the centromeric heterochromatin of the $X$.

\section{References}

Ananiev, E. V., Barsky, V. E., Ilyin, Y. V. and Churikov, N. A. 1981. Localization of nucleoli in Drosophila melanogaster polytene chromosomes. Chromosoma (Berl.) 81: 619-628.

Basile, R., Casartelli, C. and Guevara, M. 1970. Nucleic acids synthesis during the 3rd molt period of Rhynchosciara americana. Rev. Bras. Biol. 30: 291-296.

Brito da Cunha, A., Pavan, C., Morgante, J. S. and Garrido, M. C. 1969. Studies on cytology and differentiation in Sciaridae. II. DNA redundancy in salivary gland cells of Hybosciara fragilis (Diptera, Sciaridae). Genetics (Supplement) 61 (1): 335-349.

Buys, Ch. H. C. M. and Osinga, J. 1980 Abundance of protein-bound sulfhydryl and disulfide groups at chromosomal nucleolus organizing regions. A cytochemical study on the selective silver staining of NORs. Chromosoma (Berl.) 77: 1-11.

Gambarini, A. G. 1972. Estudos sôbre os genes responsáveis pela síntese de RNA ribossômico em Rhynchosciara. Doctoral Thesis. Dept. of Biochemistry, Univ. of Sáo Paulo (Brasil).

Gerbi, S. A. 1971. Localization and characterization of the ribosomal RNA cistrons in Sciara coprophila. J. Molec. Biol. 58: 499-511.

Goodpasture, C. and Bloom, S. E. 1975. Visualization of nucleolar organizer regions in mammalian chromosomes using silver staining. Chromosoma (Berl.) 53: 37-50.

Guevara, M. 1971. Estudo citológico da fisiologia e diferenciaşão cromossômica durante o desenvolvimento larval de Rhynchosciara anglelae. Doctoral Thesis. Dept. of Biol. Sci., Univ. of São Paulo (Brasil).

Hennig, W., Link, B. and Leoncini, O. 1975. The location of the nucleolus organizer regions in Drosophila hydei. Chromosoma (Berl.) 51: 57-63.

Hernández-Verdun, D., Hubert, J., Bourgeois, C. A. and Bouteille, M. $1980 . \quad$ Ultrastructural locazation of Ag-NOR stained proteins in the nucleolus and in other nucleolar structures. Chromosoma (Berl.) 79: 349-362.

Lefevre, G. 1976. A photographic representation and interpretation of polytene chromosomes of Drosophila melanogaster. In The Genetics and Biology of Drosophila. (M. Ashburner and E. Novitsky, eds.). Vol. la, pp. 29-66. Acad. Press.

Levitan, M. 1970. Chromosomal breaks with attachments to the nucleolus. Chromosoma (Berl.) 31: $452-467$.

Olvera, R. O. 1969. The nucleolar DNA of three spcies of Drosophila in the hydei complex. Genetics (Supplement) 61 (1): 245-249.

Pardue, M. L., Gerbi, S. A., Eckhardt, R. A., and Gall, J. G. 1970. Cytological localization of DNA complementary to ribosomal RNA in polytene chromosomes of Diptera. Chromosoma (Berl.) 29: 286-290.

Pessacq, T. P. 1974. Structural changes in the chromosomes of Malpighian tubes of Rhynchosciara americana (Diptera) during normal larval development and after temperature and 
hormonal treatment. Experientia 30: 279-282.

- and Vidal-Rioja, L. 1975. Structural aspects of the nucleolus and its associated heterochromatin in neurons. Cytologia 40: 129-134.

Schäfer, U. and Kunz, W. 1975. Two separated nucleolus organizers on the Drosophila hydei Y chromosome. Molec. Gen. Genet. 137: 365-368.

Simões, L. C. G. 1967. Síntese de DNA durante o desenvolvimento larval de Rhynchosciara sp. Doctoral Thesis. Dept. of Biol. Sci, Univ. of São Paulo (Brasil).

Stockert, J. C., Colman, O. D., Fernández Gómez, M. E. and Giménez Martín, G. 1969. Nucleolar structure in root-tip cells of Allium cepa. Experientia 25: 1306-1307.

Tantravali, R., Miller, D. A., Dev, V. G. and Miller, O. J. 1976. Detection of nucleolus organizer regions in chromosomes of human, chimpanzee, gorilla, orangutan and gibbon. Chromosoma (Berl.) 56: 15-27. 